\title{
Babesia spp. infection in dogs from rural areas of Sáo Paulo State, Brazil
}

\author{
Infecção por Babesia spp. em cães de áreas rurais do estado de São Paulo, Brasil \\ Lucia Helena O'Dwyer*; Viviane Von Ah Lopes; Adriano Stefani Rubini; \\ Karina Dos Santos Paduan; Paulo Eduardo Martins Ribolla
}

Departamento de Parasitologia, Instituto de Biociências de Botucatu - IBB, Universidade Estadual Paulista - UNESP

Received May 31, 2008

Accepted February 27, 2009

\begin{abstract}
The status of Babesia spp. infection in dogs from rural areas of São Paulo State, Brazil was studied. For this, 150 animals were examined by blood smears and by PCR; the presence of tick infestation was also investigated. By the blood smear examination, 3 animals (2\%) were detected positive and by PCR for Babesia spp. 12 (8\%) were positive, with bands visualized in $450 \mathrm{bp}$. Rhipicephalus sanguineus or Amblyomma spp. were found on 36 (24\%) of the 150 dogs. Amblyomma species found were A. cajennense (9/36-25\%) and A. ovale (9/36-25\%). It was not possible to correlate the presence of $R$. sanguineus and the infection with Babesia spp. The sequencing of four positive samples demonstrated close identity with B. canis vogeli already characterized in Brazil.
\end{abstract}

Keywords: Babesia canis vogeli, dogs, rural areas, blood smears, PCR.

\section{Resumo}

A presença de infecção por Babesia spp. em cães de áreas rurais do Estado de Sáo Paulo, Brasil foi investigada. Para tanto, 150 cáes foram examinados por técnicas parasitológicas de esfregaços sanguíneos e moleculares (PCR), e também, foi verificada a presença de carrapatos nestes animais. Pela análise de esfregaços sanguíneos, $3(2 \%)$ dos cães estavam infectados, enquanto pela PCR, 12 (8\%) dos animais foram positivos com bandas aproximadas de 450 pares de base (pb). Foram observados 36 (24\%) cáes infestados com Rhipicephalus sanguineus ou com Amblyomma spp. As espécies de Amblyomma observadas foram A. cajennense (25\%) e A. ovale (25\%). Não foi possível correlacionar a presença de $R$. sanguineus com a infecção por Babesia spp. O seqüenciamento de quatro amostras positivas demonstrou alta identidade $\operatorname{com} B$. canis vogeli, já caracterizada no Brasil.

Palavras-chave: Babesia canis vogeli, cães, áreas rurais, esfregaço sanguíneo, PCR.

\section{Introduction}

Babesia species are intraerythrocytic tick-transmitted Apicomplexa protozoan parasites that infect a variety of vertebrate hosts. In dogs, there are two described species: Babesia canis, a large species, and B. gibsoni, a small one. The large babesias of dogs are divided into three subspecies: B. canis canis, B. c. vogeli, and B. c. rossi, depending on vector specificity, pathogenicity, antigenic properties, and molecular biological methods (UILENBERG et al., 1989; CITARD et al., 1995; HAUSCHILD et al., 1995; SCHETTERS et al., 1997; ZAHLER et al., 1998). It has been suggested that each of these subspecies is distinctive enough to assume species status on the basis of genetic characterization (CARRET et al., 1999). Recently, Birkenheuer et al. (2004) described a new species of large Babesia that was detected in a dog from North America

*Corresponding author: Lucia Helena O'Dwyer

Departamento de Parasitologia, Instituto de Biociências de Botucatu - IBB, Universidade Estadual Paulista - UNESP, Distrito de Rubiáo Júnior, s/n, CP 237 CEP 18618-000 Botucatu - SP, Brasil; e-mail: odwyer@ibb.unesp.br

Supported by: FUNDUNESP (Processo 00217/05-DFP). with clinical and hematological abnormalities consistent with babesiosis. This species presented $91.2 \%-91.6 \%$ sequence identity with the three already described subspecies of large Babesia that infect dogs, and was placed in the Babesia spp. sensu stricto clade, representing a genetically unique large Babesia sp. The species remains with no name.

The diagnosis of Babesia spp. infection is usually based on the detection of merozoites in the peripheral blood smear under a microscope.

However, such a technique is limited because of low sensitivity and the impossibility to distinguish morphologically similar strains and species (KRAUSE et al., 1996).

The use of polymerase chain reaction (PCR) has become necessary to detect and identify Babesia spp. infection effectively and has provided important taxonomic information (SCHETTERS et al., 1997; ZAHLER et al., 1998; JEFFERIES et al., 2003; BIRKENHEUER et al., 2003; BIRKENHEUER et al., 2004; PASSOS et al., 2005). 
The molecular characterization of $B$. c. vogeli in naturally infected dogs in Brazil was recently reported in isolates from Minas Gerais and São Paulo (PASSOS et al., 2005) and from Rio de Janeiro (SÁ et al., 2006). Nevertheless, in Brazil only a few epidemiological studies have been carried out and little is known about Babesia infection, especially in dogs from rural areas where the vector Rhipicephalus sanguineus is not the most prevalent dog-infesting tick.

In this study we aimed to verify the Babesia spp. infection in dogs from rural areas of São Paulo State, Brazil, using blood smear examination and PCR.

\section{Material and Methods}

To detect Babesia infection, 150 dogs from rural areas of three counties in São Paulo State (50 from Botucatu, 50 from Rio Claro, and 50 from Presidente Prudente) were examined between November 2004 and January 2005. There were 86 males and 64 females; 32 of them were under one year old and 118 were older than one year.

The smears were made with blood taken from the ear margin capillary bed, were air dried, fixed with methanol, and stained with Giemsa. For PCR, EDTA-anticoagulant blood samples were collected by puncturing the cephalic vein and stored at $-20{ }^{\circ} \mathrm{C}$ until used.

All dogs were examined for the presence of ticks, mainly on the ears, along the nape of the neck, and between the toes. The specimens found were collected and classified using the morphologic key by Aragão and Fonseca (1961).

DNA was extracted from $100 \mu \mathrm{L}$ of EDTA blood with $\mathrm{GFX}^{\mathrm{TM}}$ Genomic Blood Purification Kit (Amersham Biosciences, Piscataway, USA) according to the manufacturer's instructions. DNA samples were eluted in $100 \mu \mathrm{L}$ of "UltraPure ${ }^{\mathrm{TM}} \mathrm{DNase} / \mathrm{RNase}$-Free Distilled Water" (Gibco/Invitrogen, Carlsbad, USA). The primers Piro A1 forward (5'- AGG GAG CCT GAG AGA CGG CTA CC - 3') and Piro B reverse (5'-TTA AAT ACG AAT GCC CCC AAC - 3') were used to amplify an approximately $450 \mathrm{bp}$ region of the 18 sRNA gene, as described by Jefferies et al. (2003). Briefly, each reaction mixture $(50 \mu \mathrm{L})$ contained $0.2 \mathrm{mM}$ of each dNTP (Amersham Biosciences, Piscataway, USA), $10 \mathrm{mM}$ of Tris- $\mathrm{HCl}$ $\mathrm{pH} 9.0,1.5 \mathrm{mM}$ of $\mathrm{MgCl}_{2}, 50 \mathrm{mM}$ of $\mathrm{KCl}$ (GE Healthcare, Piscataway, USA), $0.25 \mu \mathrm{M}$ of each primer, $0.5 \mathrm{U}$ of Taq DNA polimerase (GE Healthcare, Piscataway, USA), and $5 \mu \mathrm{L}$ of DNA template. PCR amplification was performed using a programmable thermal cycler (PTC-100 MJ Research ${ }^{\text {TM }}$, INC, Waltham, USA) with the following program: an initial denaturation at $95^{\circ} \mathrm{C}$ for 15 minutes, annealing at $62^{\circ} \mathrm{C}$ for 1 minute, and extension at $72{ }^{\circ} \mathrm{C}$ for 2 minutes followed by 30 cycles of denaturation at $94^{\circ} \mathrm{C}$ for 30 seconds, annealing at $62^{\circ} \mathrm{C}$ for 20 seconds, and extension at $72{ }^{\circ} \mathrm{C}$ for 30 seconds. A final extension step at $72{ }^{\circ} \mathrm{C}$ for 7 minutes was used.

Aliquots of amplified products $(8 \mu \mathrm{L})$ were analyzed in ethidium bromide-stained $1 \%$ agarose gel by electrophoresis at $100 \mathrm{~V}$ for 30 minutes in TAE buffer and visualized under UV transluminator. The total remaining reaction products were purified by purification Kit Montage $^{\mathrm{TM}}$ PCR Centrifugal Filter Devices (Millipore, Billerica, USA). The purified products were dissolved in $20 \mu \mathrm{L}$ of TE prior to sequencing. Selected product results were confirmed by sequencing.
Sequencing of PCR products amplified from five dog blood samples was carried out in both directions using the "ABI Prism" BigDye $^{\text {тм }}$ Terminator Cycle Sequencing Ready Reaction Kit" (PE Applied Biosystems, Foster City, USA). Briefly, for each sequencing reaction $10 \mathrm{ng}$ of purified DNA was combined with $3.2 \mathrm{pmol}$ of primer (sense and/or reverse) used in the amplification reaction. Nucleic acid sequence analysis was performed on an automated Applied Biosystems 377 DNA sequencer.

The computer analysis of nucleic acid sequence data was performed using MERGER package software. The multiple sequence alignment method and a neighbor-joining phylogenetic tree (SAITOU and NEI, 1987) was constructed using the Clustal W program (THOMPSON et al., 1994). The bootstrap test was applied to estimate the confidence of branching patterns of the neighbor-joining tree (FELSENSTEIN, 1985). Divergences were estimated by the two-parameter method using the MEGA "Molecular Evolutionary Genetics" software (KUMAR et al., 2004) in the final documentation.

Results of microscopy were compared using the Kappa test (COHEN, 1960) and results of PCR and the proportion of positive tests were compared using the Chi-square test. A value of $\mathrm{p}<0.05$ was considered significantly different. The studied variables were analyzed statistically using the Goodman contrast test between and within multinomial proportions (GOODMAN, 1965).

\section{Results}

Babesia spp. infection was detected in the blood smear of three (2\%) dogs: two of the dogs examined in Botucatu and one from Presidente Prudente. By PCR, 12 (8\%) samples were positive by showing the $450 \mathrm{bp}$ product amplification (Figure 1). Four positive samples were from the dogs from Botucatu, six from the dogs from Rio Claro, and two from the dogs from Presidente Prudente, without statistically significant difference $(\mathrm{p}>0.05)$. Also, there were no differences when gender or age were considered.

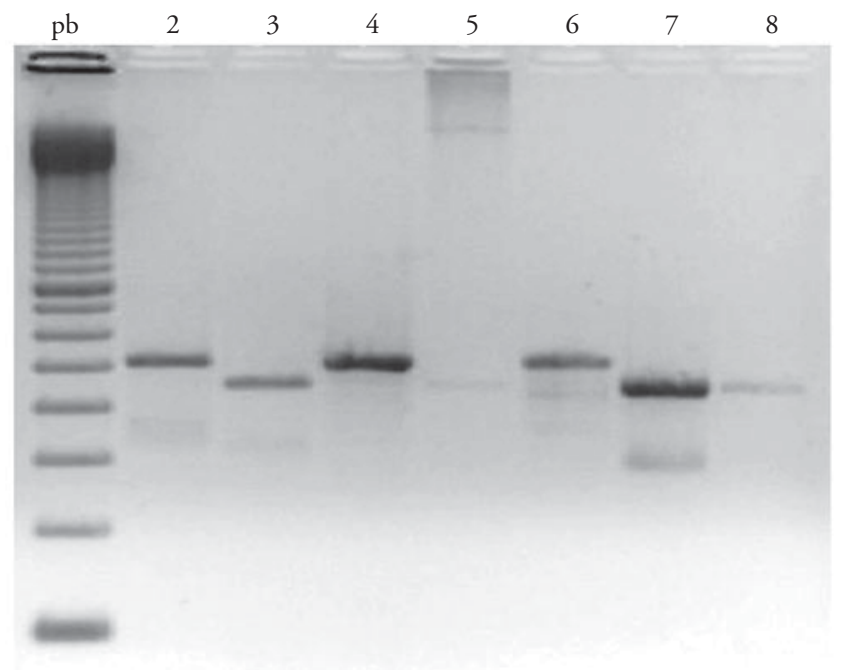

Figure 1. Ethidium bromide-stained 2\% agarose gel showing amplification of a $450 \mathrm{bp}$ product for Babesia-positive samples (lanes 3, 5, 7, and 8) and 520 bp product for Hepatozoon-positive samples (lanes 2, 4, and 6). (pb) Molecular marker. 
Four samples of the $12 \mathrm{dogs}$ PCR positive for Babesia infections were sequenced. The sequences were compared with other sequences from GenBank and had 100\% identity with B. c. vogeli from urban areas of Brazil (GenBank accession number AY371196) (PASSOS et al., 2005) and from Japan (GenBank accession number AB083374) (Figure 2).

The primers Piro A1 and Piro B were designed to amplify Babesia species (JEFFERIES et al., 2003). Nevertheless, some animals showed a band with about $500 \mathrm{bp}$, higher than the one corresponding to the Babesia band (Figure 1). Sequencing of four of these samples showed that they were of Hepatozoon canis, with close identity with an already reported sample found in Brazil (RUBINI et al., 2005).

Ticks were collected from 36 (24\%) of the dogs; 19 infested with $R$. sanguineus, nine with $A$. cajennense, two with both $R$. sanguineus and $A$. cajennense, and nine with $A$. ovale. One specimen of Amblyomma was at nymph stage and could not be identified. The distribution of the ticks within the counties is shown in Table 1. There was not a positive correlation with the Babesia infection and the infestation by $R$. sanguineus (Table 2 ).

\section{Discussion}

Babesia spp. are important tick-borne protozoa of wild and domestic canidae. Since the geographic range of specific piroplasms appears to be expanding (CRIADO-FORNELIO et al., 2004), location should not be used as the sole criterion for species or subspecies identification. It is diagnostically important to determine the species, subspecies, and genotypes that cause canine babesiosis, as the virulence, prognosis, and response to antibabesial drugs may be different for each organism (BIRKENHEUER et al., 2003). Besides, in Spain 12 asymptomatic dogs were analyzed by seminested PCR and sequencing, and three healthy dogs were positive for B. equi (Theileria equi) (CRIADO-FORNELIO et al., 2003). Also, a new species of large Babesia was described in the USA (GenBank accession number AY618928) (BIRKENHEUER et al., 2004). These findings demonstrate the importance of molecular studies and molecular characterization of canine piroplasm species, since new species and new hosts have been described.

In Brazil, few studies have been done in the country and little is known about the epidemiological aspects in rural dogs (PASSOS et al., 2005). Characterization of Babesia isolates on a molecular basis was performed by Passos et al. (2005) and Sá et al. (2006) in urban dogs, and B. c. vogeli was found to be the only infecting species. However, those studies did not analyze samples from dogs from rural areas. Our study shows that Babesia infection is not as prevalent in rural areas as in urban areas, where $B$. canis is endemic (PASSOS et al., 2005).

Ribeiro et al. (1990) detected $66.9 \%$ of anti-B. canis (sensu lato) - antibodies in dogs from an urban area. O'Dwyer et al. (2001) observed $5.2 \%$ of infected dogs by blood smear examination in a rural area. In the present study, $2 \%$ of the dogs were diagnosed by microscopic examination, and $12 \%$ of the dogs by PCR. As PCR is a sensitive test, we believe that this is a low prevalence. As far as we know, no other studies have been done with dogs from the same areas, to which our results can be compared.
Rhipicephalus sanguineus is not as frequent in rural areas as in urban areas but it may occur when the rural dogs are maintained within a kennel (LABRUNA and CAMPOS PEREIRA, 2001). In our study we observed 19 dogs infested with $R$. sanguineus (25\%). Nevertheless, $R$. sanguineus infestation was more common in $B$. c. vogeli negative dogs than in positive ones.

These results could be explained by the low number of infected dogs that may hinder the correlation between infection and tick infestation. The number of infected dogs may be insufficient to assure infection by $R$. sanguineus and this could explain the number of infested dogs that are negative for $B$. c. vogeli. We did not observe differences among the three counties in relation to the number of infected dogs either; neither there was a difference when gender and age were considered. We expected the younger dogs to be more infected.

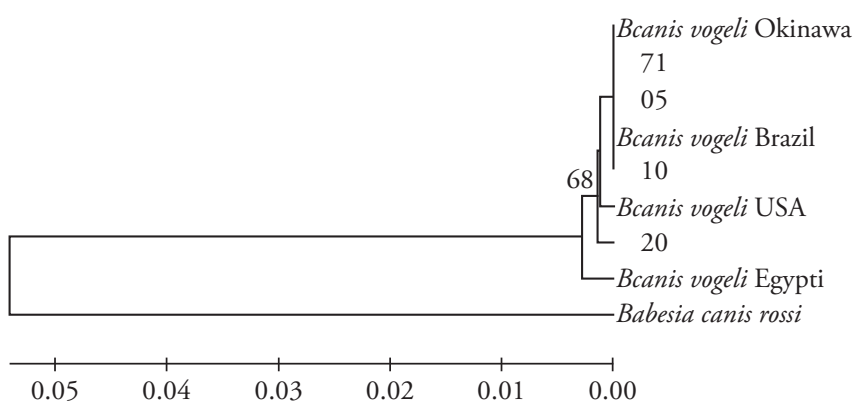

Figure 2. Neighbor-joining tree based on Babesia rDNA gene. Phylogenetic relationships among Babesia canis vogeli isolate detected in rural area $(5,10,71)$ and sequences registered in GenBank based on partial nucleotide sequences of the $18 \mathrm{~S}$ rRNA. The number at the node is the proportion of 50 bootstrap. GenBank accession numbers from the isolates were: $B$. canis from Okinawa - AY077719; B. canis vogeli from Brazil - AY371196; B. canis vogeli from USA - AY371198; B. canis vogeli from Egypt - AY371197.

Table 1. Ticks species found infesting dogs from rural areas of three counties of São Paulo State, Brazil.

\begin{tabular}{lccc}
\hline \multirow{1}{*}{ Ticks } & Botucatu & Rio Claro & $\begin{array}{c}\text { Presidente } \\
\text { Prudente }\end{array}$ \\
\cline { 2 - 4 } & $\mathbf{n}(\%)$ & $\mathbf{n}(\%)$ & $\mathbf{n}(\%)$ \\
\hline Rhipicephalus sanguineus & $5(29.4)^{\mathrm{A}, \mathrm{a}}$ & $10(76.9)^{\mathrm{A}, \mathrm{a}}$ & $4(80.0)^{\mathrm{A}, \mathrm{a}}$ \\
Amblyomma cajennense & $7(41.1)^{\mathrm{A}, \mathrm{a}}$ & $2(15.3)^{\mathrm{B}, \mathrm{ab}}$ & $0^{\mathrm{B}, \mathrm{b}}$ \\
A. ovale & $6(35.2)^{\mathrm{A}, \mathrm{a}}$ & $2(15.3)^{\mathrm{B}, \mathrm{a}}$ & $1(20.0)^{\mathrm{AB}, \mathrm{a}}$ \\
Total & $18(100)$ & $14(100)$ & $5(100)$ \\
\hline
\end{tabular}

The lower case letters in the columns and the capital letters in the rows indicate statistically significant differences $(\mathrm{p}<0.05)$ by the Goodman test.

Table 2. Correlation between Babesia spp. infection, diagnosed by PCR, and the presence of Rhipicephalus sanguineus on dogs in rural areas of São Paulo State, Brazil.

\begin{tabular}{cccc}
\hline \multicolumn{4}{c}{ Babesia spp. infection } \\
\hline Rhipicephalus sanguineus & Positive & Negative & Total \\
\hline Infected & $5^{\mathrm{A}, \mathrm{a}}$ & $14^{\mathrm{B}, \mathrm{b}}$ & 19 \\
Not infected & $7^{\mathrm{A}, \mathrm{b}}$ & $124^{\mathrm{A}, \mathrm{a}}$ & 131 \\
& $12(100 \%)$ & $138(100 \%)$ & 150 \\
\hline
\end{tabular}

The lower case letters in the columns and the capital letters in the rows indicate statistically significant differences $(\mathrm{p}<0.05)$ by the Goodman test. 
In rural areas in Brazil, the low prevalence of the vector $R$. sanguineus may lead to the low prevalence of B. c. vogeli infection. Therefore, the dogs do not acquire immunity to Babesia infection and may be predisposed to show clinical signs if infected.

The primers Piro A1 and Piro B, which were described as being specific to Babesia spp, could also detect Hepatozoon species. PCR cross reaction between Babesia and Hepatozoon were also obtained by Oyamada et al. (2005) using the primers Babesia F. and Babesia R. Oyamada et al. (2005) discussed that these primers could be successfully used to detect Babesia and Hepatozoon simultaneously and this provided an easy screening method to detect both parasites in a single PCR. But specific primers for both species should be designed to evaluate with more accuracy each infection when both parasites are present.

It has been suggested that other PCR protocols could be tested to differentiate canine piroplasm species (MARTIN et al., 2006; JEFFERIES et al., 2007). The subspecies that was detected infecting the dogs of rural areas is B. c. vogeli, with $100 \%$ of identity with the B. c. vogeli already described in Brazil (PASSOS et al., 2005). As eight samples were not sequenced, we could not confirm that these samples were of B. c. vogeli or B. gibsoni since there is only a small difference between the amplification products of these two species. Trapp et al. (2006) described the presence of genotype Asia in dogs from Brazil. The studies on this subject must be expanded to amplify the knowledge on the canine piroplasm infection in Brazil.

\section{References}

ARAGÃO, H.; FONSECA, F. Notas de Ixodologia. VIII. Lista e chave para os representantes da fauna ixodológica brasileira. Memórias do Instituto Oswaldo Cruz, v. 59, n. 2, p. 115-130, 1961.

BIRKENHEUER, A. J.; LEVI, M. G.; BREITSCHWERDT, E. B. Development and evaluation of a seminested PCR for detection and differentation of Babesia gibsoni (Asian genotype) and B. canis DNA in canine blood samples. Journal of Clinical Microbiology, v. 41, n. 9, p. 4172-4177, 2003.

BIRKENHEUER, A. J. et al. Detection and molecular characterization of a novel large Babesia species in a dog. Veterinary Parasitology, v. 124, n. 3-4, p. 151-160, 2004.

CARRET, C. et al. Babesia canis canis, Babesia canis vogeli, Babesia canis rossi: differentiation of the three subspecies by a restriction fragment length polymorphism analysis on amplified small subunit ribosomal RNA genes. Journal of Eukaryotical Microbiology, v. 46, n. 3, p. 298-303, 1999.

CITARD, T. et al. Babesia canis: evidence for genetic diversity among isolates revealed restriction fragment length polymorphism analysis. Tropical Medical Parasitology, v. 46, n. 3, p. 172-179, 1995.

COHEN, J. A coefficient of agreement for nominal scales. Educational and Psychological Measurement, v. 20, n. 1, p. 37-46, 1960.

CRIADO-FORNELIO, A. et al. Molecular studies on Babesia, Theileria and Hepatozoon in southern Europe Part I. Epizootiological Aspects. Veterinary Parasitology, v. 113, n. 3-4, p. 189-201, 2003.

CRIADO-FORNELIO, A. et al. The "Expanding Universe" of Piroplasmas. Veterinary Parasitology, v. 119, n. 43, p. 337-345, 2004.

FELSENSTEIN, J. Confidence limits of phylogenies: an approach using the bootstrap. Evolution, v. 39, n. 4, p. 783-791, 1985.

GOODMAN, L. A. On simultaneous confidence interval for multinomial proportions. Technometrics, v. 7, n. 2, p. 247-254, 1965.
HAUSCHILD, S.; SHAYAN, P.; SCHEIN, E. Characterization and comparison of merozoite antigens of different Babesia canis isolates by serological and immunological investigations. Parasitology Research, v. 81, n. 8, p. 638-642, 1995.

JEFFERIES, R. et al. Two species of canine Babesia in Australia: detection and characterization by PCR. Journal of Parasitology, v. 89, n. 2, p. 409412, 2003

JEFFERIES, R.; RYAN, U. M.; IRWIN, P. J. PCR-RFLP for the detection and differentiation of the canine piroplasm species and its use with filter paper-based technologies. Veterinary Parasitology, v. 144, n. 1-2, p. 20-27, 2007.

KRAUSE, P. J. et al. Comparison of PCR with blood smear and inoculation of small animals for diagnosis of Babesia microti parasitemia. Journal of Clinical Microbiology, v. 34, n. 11, p. 2791-2794, 1996.

KUMAR, S.; TAMURA, K.; NEI, M. Mega3: Integrated software for molecular evolutionary genetics analysis and sequence alignment. Briefings in Bioinformatics, v. 5, n. 2, p. 150-163, 2004.

LABRUNA, M. B.; CAMPOS PEREIRA, M. Carrapato em cães no Brasil. Clínica Veterinária, v. 30, p. 24-32. 2001.

MARTIN, A. R. et al. Babesia canis vogeli: a novel PCR for its detection in dogs in Australia. Experimental Parasitology, v. 112, n. 1, p. 63-65, 2006.

O'DWYER, L. H.; MASSARD, C. L.; SOUZA, J. C. P. Hepatozoon canis infection associated with dog ticks of rural areas of Rio de Janeiro State, Brazil. Veterinary Parasitology, v. 94, n. 3, p. 143-150, 2001.

OYAMADA, M. et al. Detection of Babesia canis rossi, B. canis vogeli and Hepatozoon canis in dogs in a village of eastern Sudan by using a screening PCR and sequencing methodologies. Clinical and Diagnostic Laboratory Immunology, v. 12, n. 11, p. 1343-1346, 2005.

PASSOS, L. M. F. et al. First molecular detection of Babesia vogeli in dogs from Brazil. Veterinary Parasitology, v. 127, n. 1, p. 81-85, 2005.

RIBEIRO, M. F. B. et al. Frequência de anticorpos fluorescentes anti-Babesia canis em cáes de Belo Horizonte, Minas Gerais. Arquivo Brasileiro de Medicina Veterinária e Zootecnia, v. 42, n. 6, p. 511-517, 1990.

RUBINI, A. S. et al. Molecular identification and characterization of canine Hepatozoon species from Brazil. Parasitology Research, v. 97, n. 2, p. 91-93, 2005.

SÁ, A. G. et al. Detection and molecular characterization of Babesia canis vogeli from naturally infected Brazilian dogs. International Journal of Applied Research in Veterinary Medicine, v. 4, n. 2, p. 163-168, 2006.

SAITOU, N.; NEI, M. The neighbor-joining method: a new method for reconstructing phylogenetic trees. Molecular Biology Evolution, v. 4, n. 4, p. $406-425,1987$.

SCHETTERS, T. P. et al. Different Babesia canis isolates, different diseases. Parasitology, v. 115, n. 5, p. 485-493, 1997.

THOMPSON, J. D. et al. Improving the sensitivity of progressive multiple sequence alignment through sequence weighting, position specific gap penalties and weight matrix choice. Acids Research, v. 22, n. 22, p. 4673 $4680,1994$.

TRAPP, S. M. et al. Babesia gibsoni genotype Asia in dogs from Brazil. Veterinary Parasitology, v. 141, n. 1-2, p. 177-180, 2006.

UILENBERG, G. et al. Three groups of Babesia canis distinguished and a proposal for nomenclature. Veterinary Quarterly, v. 11, n. 1, p. 33-40, 1989.

ZAHLER, M. et al. Characteristic genotypes discriminate between Babesia canis isolates of differing vector specificity and pathogenicity to dogs. Parasitology Research, v. 84, n. 7, p. 544-548, 1998. 